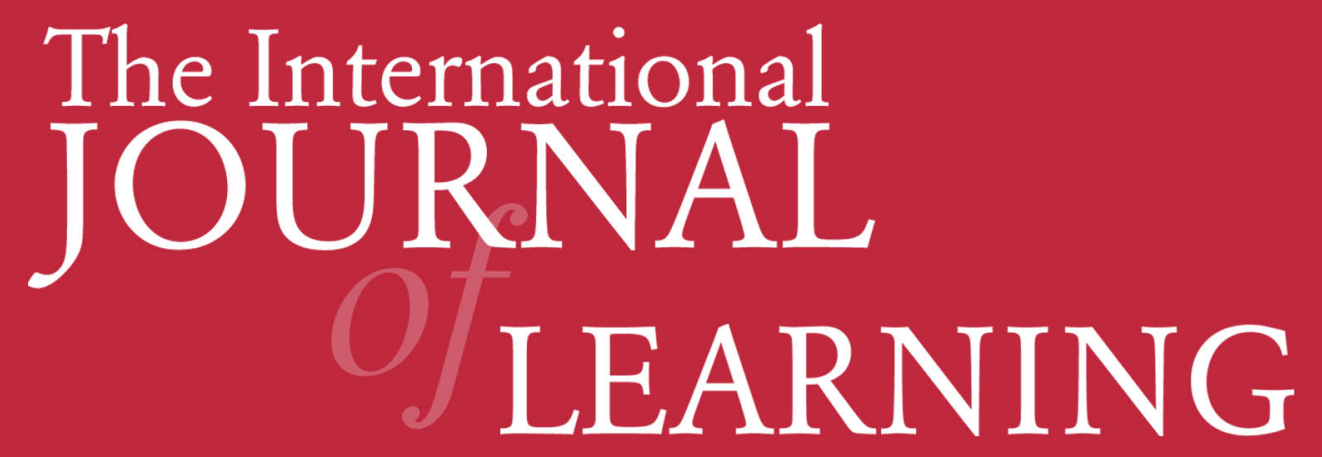

Using Imagination to Engage Future Teachers in a Critical Pedagogy in the Tertiary Classroom

\author{
Lynne Noone \\ Patricia Anne Cartwright
}




\section{INTERNATIONAL JOURNAL OF LEARNING}

http://www.Learning-Journal.com

First published in 2005/2006 in Melbourne, Australia by Common Ground Publishing Pty Ltd www.CommonGroundPublishing.com.

(C) 2005/2006 (this paper), the author(s)

(C) 2005/2006 (selection and editorial matter) Common Ground

All rights reserved. Apart from fair use for the purposes of study, research, criticism or review as permitted under the Copyright Act (Australia), no part of this work may be reproduced without written permission from the publisher. For permissions and other inquiries, please contact <cg-support@commongroundpublishing.com>.

ISSN: 1447-9494 (print), 1447-9540 (online)

Publisher Site: http://www.Learning-Journal.com

The INTERNATIONAL JOURNAL OF LEARNING is a peer refereed journal. Full papers submitted for publication are refereed by Associate Editors through anonymous referee processes.

Typeset in Common Ground Markup Language using CGCreator multichannel typesetting system http://www.CommonGroundSoftware.com. 


\title{
Using Imagination to Engage Future Teachers in a Critical Pedagogy in the Tertiary Classroom
}

\author{
Lynne Noone, University of Ballarat, Australia \\ Patricia Anne Cartwright, Australian Catholic University, Australia
}

\begin{abstract}
This paper reports aspects of our action research about incorporating imagination into teaching strategies which foster critical thinking in the tertiary classroom. Theoretical concepts of imagination, critical pedagogy and storying inform the two strategies outlined. Each strategy is discussed within an action research cycle of planning, implementation, observation and reflection. The data presented consist of sample stories written by students as outcomes of each teaching strategy, analysis of these stories and reflections on the processes. The research suggests that finding pedagogical ways to utilise Maxine Greene's (1995) view that imagination is generated from confrontations of ideas can encourage students to think differently and critically.
\end{abstract}

Keywords: Imagination, Storying, Critical Pedagogy, Teacher Education, Action Research, Tertiary Teaching

\section{Introduction}

$\mathrm{I}$

N TRYING TO engage future teachers in a critical pedagogy through the use of imagination, we find ourselves confronting a range of issues. As academics employed in the higher education sector, we are troubled by the corporatisation and marketisation of tertiary institutions and the future of university education. As teacher educators, we are concerned about the government and semi-government regulators of the teaching profession who increasingly wish to 'fix' teacher education (for example, the 2004 review of teacher education by the Victorian State Government which is the employer of the $70 \%$ of teachers in public schools in the state, and the recently announced inquiry into the teaching of literacy by the Australian Government, which funds the student places at universities for the study of education). As members of the education community, we acknowledge the immediacy of the requirements and discourses of schools and practitioners and the future directions of schools. As teachers of young adults who wish to become knowledgeable about education in order to gain employment in the field, we confront the realities of young people, the nature of education and our own curriculum and pedagogy.

Our concern is what happens in the tertiary classroom. Our task is to teach in contemporary cultural, political and economic circumstances about the current nature, requirements and constraints of schooling - but also to imagine for ourselves, and encourage our students to imagine, that things could be otherwise. As academics, teacher educators and tertiary teachers who profess a commitment to social justice in education, we work with the possibilities which are presented, or constructed, in our daily professional lives.

In this paper we: (a) describe the context of our work; (b) outline some of the theoretical concepts informing our practice; (c) describe two teaching learning strategies that use imagination to engage students in critical thinking, and present some of the data from our work with the students; and (d) discuss some of the issues for us as tertiary teachers of teachers which have become apparent when we try to engage students' imagination.

\section{Context of Our Work}

The material on which this paper is based is derived from our reflections on classroom pedagogical incidents with undergraduate education students in two small provincial universities in Victoria, Australia. Each of us engages in on-going action research about our teaching. Each of us teaches units in different sub-disciplines of education - one person in literacy education, and the other in sociology and politics of education.

Our students are mainly from rural backgrounds, few with high TER (Tertiary Entrance Ranking) scores; many the first in their families to enter tertiary education; almost all of white Anglo-Saxon background; and some who don't want to be in this course at this place at this time. They have varying motivations, world views and capacities. Bartholomae (1988) has suggested that students have to 'invent' the university. That is, they have to learn to speak the language, and to take on the varying ways of knowing, evaluating, reporting and arguing that 
define the discourses of the academic community. For teacher education students, it is not only the university that they have to 'invent'; they also have to 'invent' the profession of teaching. That is, they have to learn to speak the language, and to take on the varying ways of knowing, evaluating, reporting, arguing and acting that define the discourses of the teaching/school community. It is in this context that we attempt to intervene in their understandings of the taken-for-granted to present a view of other possibilities. Like Middleton (1993), we find Maxine Greene's (1986) question most pertinent: 'What might a critical pedagogy mean for those of us who teach the young at this peculiar and menacing time?' (Greene, 1986, p. 440 in Middleton, 1993, p. 2).

\section{Theory Informing Our Practice}

\section{Engagement and Imagination}

In our view, it is not enough for us as critical teacher educators to raise the consciousness of our students through aligning ourselves, and them, with current socio/economic/educational critiques - the basis of much exposition of critical pedagogy (for example, Giroux, 1988, Freire \& Shor, 1987; Kincheloe,1993; Freire \& Macedo, 1987; McLaren, 1995; Kanpol, 1999). As Ellsworth (1989) convincingly argues in her critique of critical pedagogy, attempting to enlighten students about the right (or, perhaps, left) way to see the world is to proselytize for a 'more correct' view - a process that is merely another version of the repressive forms of education to which they have become accustomed and a process that can lead students to feel demoralized, immobilised and hopelessly at the mercy of existing social relationships of domination.

Greene (1995) claims that "of all our cognitive powers, imagination is the one that permits us to give credence to alternative realities. It allows us to break with the taken-for-granted, to set aside the familiar distinctions and definitions" (p. 3). Imagination is what occurs as a person encounters new ideas and engages in confrontations with arguments and controversies and turns towards the world. For Greene, this is a process of becoming "wide-awake" (Greene \& Griffiths, 2003, p. 88), which she likens to Freire's process of conscientization. The problem for a critical pedagogy is how to facilitate the process of awakening. Greene believes that for this to happen, there must be a shock, a crisis made from a combination of negative critique and questioning one's own existence in relation to others (Britzman \& Dippo, 2003, p.133).

Harnessing imagination in pedagogy may be a way to "take them [students] beyond their current horizons to consider perspectives and issues that they would not normally entertain" (Zeichner \& Liston,
1991, p. 193). Egan and Madoc-Jones (2005) suggest that "imagination is not some idle or ornamental faculty, but is the hard working core of educational engagement" (p. 2), which enables "other ways of thinking” (Egan, 1992, p. 42). As Fettes (2005, p. 4) points out, bringing students to understand the powerful connection between imagination and lived reality is a necessary and primary task of teacher education. To do so means engaging their emotions, feelings and empathy (Trotman, 2005, p. 51).

\section{A Critical Literacy Pedagogy}

Finding a way to utilise imagination means finding a pedagogy. Specifically we foreground writing as pedagogy. With Brodkey (1987), we believe that writing is a social practice, that we use writing to shape meaning, to imagine other possibilities, and that we write our way to understanding. In our classrooms we - teacher and students - talk, write and read. It is in talking, writing and reading that the world is named, ideas are encountered, formulated and engaged with. Clearly there are also physical actions and physical surroundings which constitute our classrooms, and the world of social praxis outside our classroom which shape the nature of our classes. But what we do in the classroom is linguistic. For us then, it seems a logical place from which to begin thinking about the possible use of imagination in a critical pedagogy.

While recognizing the theoretical risks of conflating the 'family trees' of critical pedagogy, critical literacy (Freebody \& Muspratt, 1992; Lankshear, 1997) and Greene's version of "wakefulness", we nevertheless envisage a critical literacy pedagogy as a way of developing in students-who-would-beteachers a range of knowledges and skills as they develop a critical view of society, culture and education and a sense that it could be otherwise. We ask them to imagine 'other' situations and to talk and write about what these might be. Through a range of classroom pedagogical strategies centering on a variety of text types, ideas expressed in language are constructed, interrogated, analysed, challenged and reconstructed in critical ways.

\section{Teaching as Action Research}

Our action research is both action and research by us as teachers. We draw from the work on teacher narrative (see, for example, Clandinin \& Connelly, 2000; Jalongo \& Isenberg, 1995) which acknowledges teaching as an uncertain business, one whose character results from the sense which teachers make of the immediate and broader contexts in which they act. Action research has a strong emphasis on reflection and inquiry. Reflection in action research is 'critical' in that it centres not only on the everyday 
aspects of teaching and learning, but also on the social, political and institutional contexts in which such activities occur. While the action research process is usually described as planning, acting, observing and reflecting, we found that this did not happen as discrete and tidy phases of research. We did find, however, that our teacher stories capture the sense we make of the action research cycles in our teaching. They provide a powerful means of professional development when re-visited by us for critical dialogical reflection. The teacher story contained in this paper concerns the action research cycle in which we planned, implemented, observed and reflected upon imagination-based writing tasks undertaken by students.

In the following section, we describe instances of an action research cycle in which two of the imagination based strategies were planned, implemented and reflected on. Each strategy attempts to engage students' imagination, through writing, as a means of getting them to think differently and critically. We have only used single examples of the data collected for the purposes of this paper. However, we are developing a schema to categorise the nature of imagination in the stories across the whole cohort, in order to identify the different ways that imagination has been used critically.

\section{Engaging Students through Imagination}

\section{Strategy 1 - Writing a Bounded Story}

One of the ways we have found useful as a means of 'jarring' our students into thinking differently is through inviting them to enter a storytelling culture, which, according to McDrury \& Alteris (2002), can foster reflective learning and invite them to enter different realities. If we take Greene's notion of imagination as a confrontation with ideas, unfamiliar ideas are set as the boundaries with which existing understandings have to collide in order to make a new sense in the story.

In a class on Curriculum Theory, Lynne set students the task of writing a short story about a schoolbased incident in which some knowledge is constructed for and by a learner. The boundaries of the story were set by curriculum concepts specified in four designated articles and the guiding questions about the content and format of the story. In writing the story in the classroom, first year students were able to draw on their own recent school experiences, the schooling experiences of others, an imaginary circumstance or a circumstance that they would prefer to happen. But whatever the source of inspiration, the account had to be fictional, but 'life-like'. The students were directed that the narrative should have a setting, characters, dialogue, a beginning, an event, and a denouement... and interesting use of language. They were also directed that the narrative should demonstrate what the learner learnt, how and why the learner learnt this knowledge, contested views and values about worthwhile knowledge, power relations inside and outside schooling.

Initially, the students were required to engage in individual writing of a story for approximately 20 minutes. They were then paired with a peer, the task being to critique each author about the characters in the story. Each author's explanation to their critical friend required the author to engage with the motivations and emotions of each character in their story. As they discuss each other's story, Lynne circulates around the room, trying to get a sense of the issues that are emerging. She then uses this knowledge to question the students, as a class, or in pairs.

The data collected were the students' stories, and students' comments on the task of writing the story. Lynne's reflective journal about her actions and observations of the students' engagement with the task appear in a later section.

Figure 1 is a sample story from this exercise. Following this is our reflection on this story. 


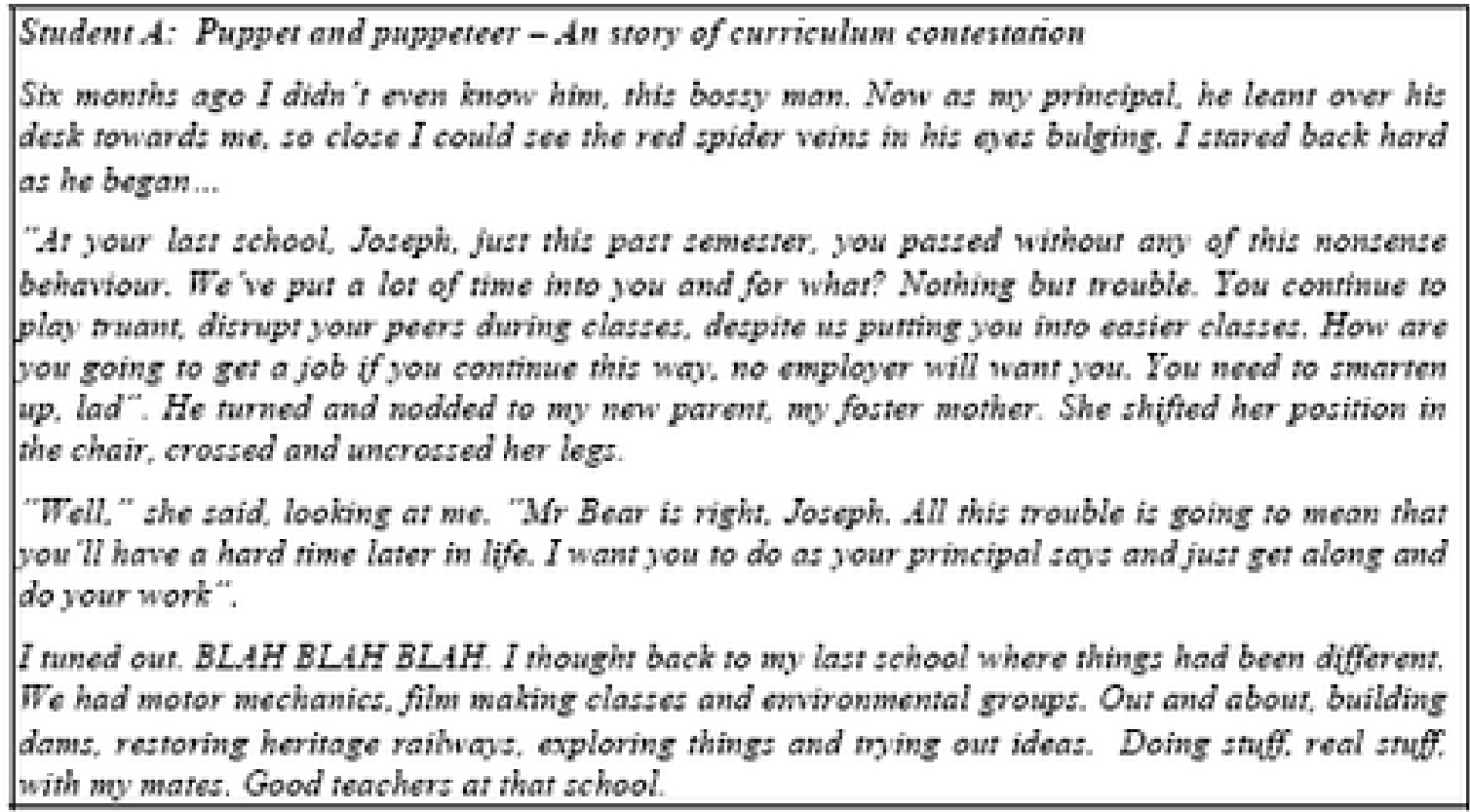

Figure 1: Student A's Story

In constructing this story, Student A has made numerous decisions in regard to plot, point of entry for the story, characters, narrator, dialogue and so on. She chose a plot that is based on her existing knowledge of an aspect of contemporary school life, of patterns of power relations and of key curriculum issues. The dialogue brings to the surface some of the tension between the characters, but it is in the narrator's thoughts that we gain a sense of the deeper tensions.

Through the actions and utterances of the characters, and the first person descriptions of the narrator's thoughts, Student A gives clues about her values and curriculum perspectives. She has had to imagine herself in the role of each character in order to consider what each might say or do, based on an empathetic understanding of such people as she understands them to exist in the contemporary world. But on the other hand, she has had to understand the curriculum concepts available through the set reading, select those which she thinks may be appropriate to the scenario she has in mind, interpret them into the types of actions or ideas to which the concepts might refer, and then translate those into actions or ideas into a form of language which is consistent with the characters.

In Figure 2, part of a student's self-evaluation is shown. It becomes apparent that she had chosen to base the story on an autobiographical event. We gain a sense of the connection with the personal as the student re-visits an event in her life, re-evaluates it, and transforms her understanding into a hopeful conviction about her future actions as a result of the story writing exercise:

Student B: Writing the story brought up old memories and also made we sad in that I could have done so much wore at the tive to address the issue. As $I$ wrote wy story Ifound nyself going over the event in ny life and seeing it as something different. It also wade we stronger in thinking about the tope of teacher $I$ want to be.

Figure 2: Student B’s Self-Evaluation

\section{Strategy 2 - Thinking within a Story}

Another way that we use stories to 'jar' our students' thinking is to establish a different world through a story and ask students to place themselves within it. The story is selected because its plot or characters are un-real. That is, the story's fantastical quality signals to the students that the rules of the form of life in the story may not be a continuation of those with which they habitually understand their world but which remain with them even as they enter the story. In a sense, we are using the story as an extended metaphor. Greene (in Greene \& Griffiths, 2003) believes that a metaphor "brings together things that are unlike, reorients consciousness which customarily connects things that are like" (p. 85). It frames ways of understanding, says Greene - sometimes to open up the world and make one look again, look differently, and sometimes to constrict the world. Our use 
of a story as an extended metaphor can be understood as doing both these things.

In Pat's unit of study for first year undergraduates, The Nature and Development of Language, students are encouraged to recognize the power of language as a social, cultural, and political activity, which shapes our beliefs and ideas about how we see ourselves and the world, and which reinforce 'acceptable' ways of being. Through participation in activities, discussions and readings, students explore various examples of this: for example, the power of advertising in influencing young people (and indeed all of us) about "what to think, believe, desire, and feel and about how to behave" (Giroux, 1998, p. 23); or the power of stories (picture books, novels, fairytales) to position readers and construct the way children, and adults, see themselves in their world (Lieberman, 1993). While a number of picture story books are used in the classroom, the following reports on the use of one picture story book in particular, which encourages students to critique traditional social roles, to envisage alternate models of female and male behaviour, and to use story as an extended metaphor.

\section{Snow White in New York (French, 1992)}

Students are allocated a character from the story, and they must write an argument in defence of their character remaining in the story. In order to do this, they must both foreground aspects of their character that are vital to the storyline as well as indicate the ways in which the other characters are both subordinate to, and dependent on, their particular character. The students must maintain the storyline, but re-think the motivations and actions of their character, and the likely interactions with other characters. Having altered one character, students are forced to continue the new logic into their consideration of the other characters, but their existing understandings in their social relationships in their real world continue to inform their consideration. Thus, their meaning making is jarred by this dilemma. What they perceive to be acceptable behaviour in society is confronted and disturbed. Figure 3 provides an example of how one student wrote her characters into her version of the story.

\section{Sndent C: Snow White: She is a role model, resilient, and a 'good girl'. She brought happiness to the people of New York through her singing. and through her exawple of miumph over adversiny. She cared for the Seven Jaszmen by keeping their house clean, and curtailing their drug use. In addition, her success as a singer brought them fame, success and money. As for the Reporter, withou Snow thite he would not have found his TRUE love; she is his soul mate and makes him happy. She also provided him with a sensarional nens story, thus giving his career a much needed boost.........}

Figure 3: Student C's Story

The example in Figure 3 follows a somewhat traditional rags-to-riches, boy-meets-girl story line, reflective of numerous stories, books, movies, and soap operas, familiar to Western culture, providing a narrative that is both familiar and naturalized as a 'normal' component of aspirations for life and love. This is an example where, despite the changed logic of the characters, the student's understanding of social relationships in the 'real' world has dominated.

The example in Figure 4 takes a somewhat different view of the story:

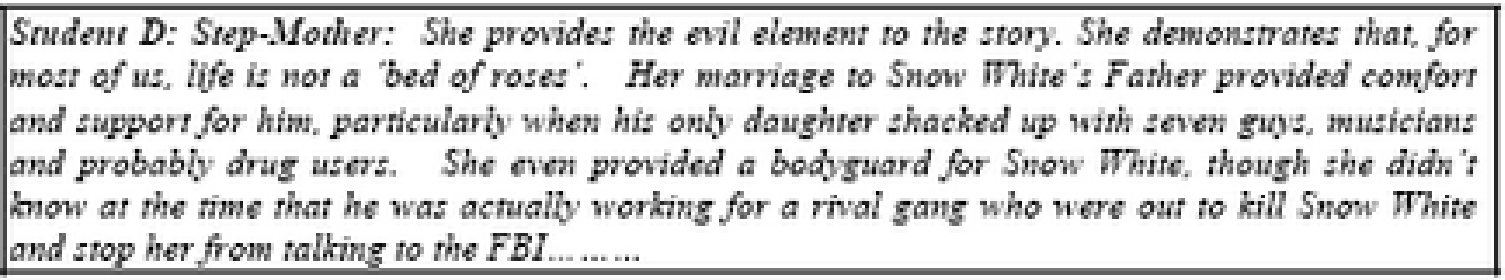

Figure 4: Student D’s Story

In this example, the student has more fully followed the logic created by the new characters which he/she has introduced. But, while this example provides a disrupted, and disruptive version of the Snow White story, there are still echoes, in the plot line of the student's existing understanding of social relation- ships in the 'real' world (Davies, 1993). Thus, the student has had to imagine an alternate landscape of meaning. 


\section{A Teacher's Story}

It is important to place these strategies and the samples of student writing in the context of the teacher's intentions, interpretations and practices.
The following extract from Lynne's journal gives an insight into the intense teacherly work which is involved in 'reading' the class and drawing upon a reservoir of teacherly knowledge, regardless of the strategy used.

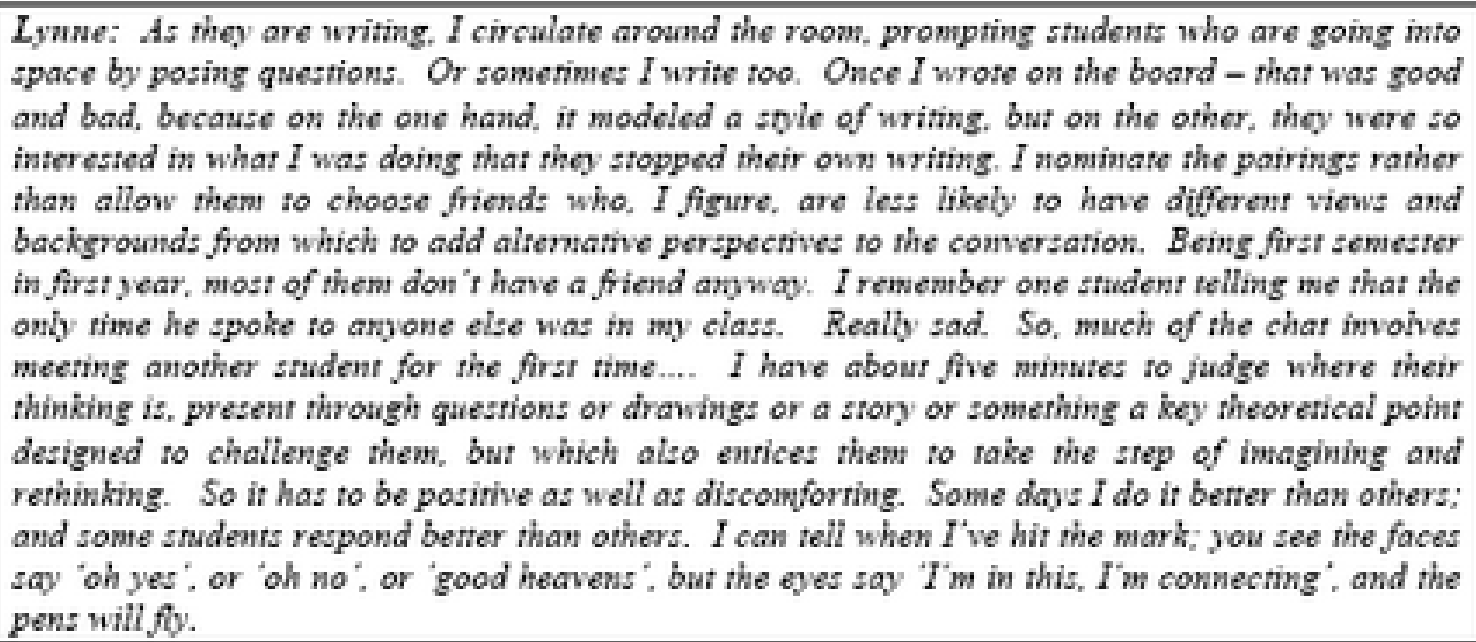

Figure 5: Lynne's Story
As an instance of a teacher's story (see, for example, Jalongo \& Isenberg, 1995; Burchell \& Dyson, 2000), this extract allows us to see inside the teacher's head as she reflectively ascribes meaning to events and personal actions in lived classroom experiences. The story combines remembering, thinking, feeling, criteria of successful pedagogy, the abstract and the concrete. And the story can be revisited and reinterpreted as Lynne encounters new concepts and experiences. That also is an act of imagination - as well as professional development. The story can also be visited and interrogated by a critical friend who can contribute a different perspective to aid analysis and re-thinking - a necessary process in order to move beyond the self-affirmation of storying, according to Burchell and Dyson (2000). The teacher's story can also be juxtaposed with student stories.

\section{Discussion}

Our attempts to use imagination to engage students in critical thinking through writing are consistent with the characteristics of criticality suggested by Burbules and Berk (1999) - contextual/non-contextual thinking, multiple interpretations, creating and dialoguing across alternatives, self-reflective willingness to think against the grain in new ways. These conditions might be necessary, but are they sufficient? Some of our attempts to create these conditions have been outlined earlier. But while the data collected from students suggests that our pedagogical interventions aimed at both engaging our students in their learning and 'jarring' understandings through imagination seem to make a difference for some students some of the time, we still have questions.

Some students, at some times, seem to resist understanding the contemporary world in terms of power relations, let alone problematising it, as the stepping-off point for thinking differently. Their view of their comfortable world informs their engagement with the content and pedagogy, as it must of course. Another student reaction to exploring a present which is discomforting or to seriously considering alternatives is the adoption of one of two types of avoidance responses. On the one hand, serious engagement with imagined alternatives may be dismissed as a case of "you're entitled to your opinion and I'm entitled to mine" - end of conversation. On the other hand, imagined alternatives which do not fit with a comfortable view of the existing world may be dismissed as 'bad' or 'mad' - again, end of conversation.

A further question is raised by the possibility that students are purely strategic in their participation in our pedagogical strategies. They may go through the motions which are interpreted as being required by us. Students learn very early in their educational experience to be strategic in the sense of working out what the teacher wants and giving it to them. Our students are no exception. To an extent, they accept our version of content as authoritative because of our institutional position of lecturers who ultimately can award a pass or fail grade. There are two issues here - one, whether students' strategic interest means that they are only ever dealing with ideas at a surface level rather than engaging at the level of actually rethinking their worldviews; two, whether our institutional power position inhibits the intent of a critical 
pedagogy. We acknowledge these difficulties, but these are the issues confronting any teacher. Nevertheless, our data suggest that these imagination based strategies do touch the students' emotions, jar their sensibilities, and cause them to think again.

\section{Conclusion}

Using imagination to engage future teachers in a critical pedagogy in the tertiary classroom is, for us, an ongoing professional and political problem; it is an ongoing conversation. We constantly see things happening or not happening in our classrooms that give us occasion to go over our practice again, and yet again - to rethink why something is or is not working. In this paper, we have outlined some episodes of our action research on teaching strategies that use imagination to foster critical thinking. The notion of imagination as a means of jarring students to think differently has informed our practice. Our research suggests that incorporating imagination into teaching strategies moves some students to think more humanely and a little more critically.

\section{References}

Bartholomae, D. (1988). Inventing the university. In M. Rose (Ed.). Perspectives on literacy. (pp. 273-285). Carbondale: South Illinois University Press.

Britzman, D. \& Dippo, D. (2003). Admitting “A perhaps”: Maxine Greene and the project of critical theory. In M. Peters, C. Lankshear \& M. Olssen (Eds.). Critical theory and the human condition. (pp. 130-139). New York: Peter Lang.

Brodkey, L. (1987). Academic writing as social practice. Philadelphia; Temple University Press.

Burbules, N. \& Berk, R. (1999). Critical thinking and critical pedagogy: Relations, differences and limits. In T. Popkewitz \& L. Fendler. (Eds.). Critical theories in education. (pp. 45-65). New York and London: Routledge.

Burchell, H. \& Dyson, J. (2000). Just a little story: The use of stories to aid reflection on teaching in higher education. Education Action Research. 8(3), 435-450.

Clandinin, D. \& Connelly, F. (2000). Narrative inquiry. San Francisco: Jossey-Bass.

Davies, B. (1993). Shards of glass: Children reading and writing beyond gendered identities. St Leonard's, NSW: Allen \& Unwin.

Egan, K. (1992). Imagination in teaching: Ages 8 - 15. London: Routledge.

Egan, K. \& Madoc-Jones, G. (2005). Editorial: Education and imagination. Teaching Education. 16(1), 1-2.

Ellsworth, E. (1989). Why doesn't this feel empowering?: Working through the repressive myths of critical pedagogy. Harvard Educational Review, 59(3), 297-324.

Fettes, M. (2005). Imaginative transformation in teacher education. Teaching Education. 16(1), 3-11.

Freebody, P. \& Muspratt, S. (Convenors). (1992). Working conference on critical literacy. Conference material. Brisbane: Griffith University.

Freire, P. \& Macedo, D. (1987). Literacy: Reading the word and the world. South Hadley, MA.: Bergin \& Garvey.

Freire, P. \& Shor, I. (1987). A pedagogy for liberation. London: Macmillan.

French, F. (1992). Snow White in New York. Melbourne: Oxford University Press.

Greene, M. (1986). In search of a critical pedagogy. Harvard Educational Review. 56(4), 427-441.

Greene, M. (1995). Releasing the imagination: Essays on education, the arts, and social change. San Francisco: JosseyBass.

Greene, M. \& Griffiths, M. (2003). Feminism, philosophy and education: Imagining public spaces. In N. Blake, P. Smeyers, R. Smith \& P. Standish (Eds.). The Blackwell guide to the philosophy of education. (pp. 73-92). New York: Blackwell Publishing.

Giroux, H. (1988). Teachers as intellectuals: Towards a critical pedagogy of learning. Westport, CT: Bergin \& Garvey.

Giroux, H. (1998). Something comes between kids and their Calvins. Channel surfing: Race talk and the destruction of today's youth. Bloomington, PA: Macmillan.

Jalongo, M. \& Isenberg, J. (1995). Teachers' stories. San Francisco: Jossey-Bass.

Kanpol, B. (1999). Critical pedagogy: An introduction. (2 ${ }^{\text {nd }}$ edition). Westport, CT: Bergin \& Garvey.

Kincheloe, J. (1993). Towards a critical politics of teacher thinking. Westport, CT: Bergin \& Garvey.

Lankshear, C. (1997). Changing literacies. Buckingham: Open University Press.

Lieberman, M. (1993) "Some day my prince will come": Female acculturation through the fairy tale. In. J. Zipes (Ed.). Don't bet on the prince: Contemporary feminist fairy tales in North America and England. England: Scholar Press.

McDrury, J. \& Alteris, M. (2002). Learning through storytelling: Using reflection in higher education. Palmerston, NZ: Dunmore Press.

McLaren, P. (1995). Critical pedagogy and predatory culture. London: Routledge.

Middleton, S. (1993). Educating feminists: Life histories and pedagogy. New York and London: Teachers College Press. Schon, D. (1983). Educating the reflective practitioner. San Francisco: Jossey-Bass.

Trotman, D. (2005). "Looking for sparks": A phenomenological study of educational practice and the imaginative life-world of primary schools. Teaching Education, 16(1), 61-72.

Zeichner, K. \& Liston, D. (1991). Teacher education and the social conditions of schooling. New York and London: Routledge. 


\section{About the Authors}

Ms Lynne Noone

Originally trained as a primary teacher and later taking part in educational politics and policy as a parent activist, Lynne currently teaches sociology and politics of education to undergraduate and graduate students of education. In recent years, she has undertaken action research on her own teaching to explore ways of developing students' critical awareness of educational matters. She has published in this area with colleague Patricia Cartwright.

\section{Dr Patricia Anne Cartwright}

Patricia has taught in primary and secondary schools, and currently teaches literacy education to undergraduate and graduate students of primary and secondary education. She has a particular interest in critical literacy, lifelong learning, values education and tertiary teaching. Together with colleague, Lynne Noone, she has led various professional development programs for tertiary colleagues. She has also been involved in a number of action research projects with schools regarding student literacy. She has published in the areas of critical literacy, writing pedagogy, action research, teacher narrative, and tertiary teaching. 
EDITORS

Mary Kalantzis, RMIT University, Australia.

Bill Cope, Common Ground, Australia.

EDITORIAL ADVISORY BOARD

Michael Apple, University of Wisconsin-Madison, USA.

David Barton, Lancaster University, UK.

James Paul Gee, University of Wisconsin-Madison, USA.

Brian Street, King's College, University of London, UK.

Kris Gutierrez, University of California, Los Angeles, USA.

Scott Poynting, University of Western Sydney, Australia.

Gunther Kress, Institute of Education, University of London.

Ruth Finnegan, Open University, UK.

Roz Ivanic, Lancaster University, UK.

Colin Lankshear, James Cook University, Australia.

Michele Knobel, Montclair State University, New Jersey, USA.

Nicola Yelland, RMIT University, Australia.

Sarah Michaels, Clark University, Massachusetts, USA.

Richard Sohmer, Clark University, Massachusetts, USA.

Paul James, RMIT University, Melbourne, Australia.

Michel Singh, University of Western Sydney, Australia.

Peter Kell, University of Wollongong, Australia.

Gella Varnava-Skoura, National and Kapodistrian University of Athens, Greece.

Andeas Kazamias, University of Wisconsin, Madison, USA

Ambigapathy Pandian, Universiti Sains Malaysia, Penang, Malaysia.

Giorgos Tsiakalos, Aristotle University of Thessaloniki, Greece.

Carey Jewitt, Institute of Education, University of London, UK.

Denise Newfield, University of Witwatersrand, South Africa.

Pippa Stein, University of Witwatersrand, South Africa.

Zhou Zuoyu, School of Education, Beijing Normal University, China.

Wang Yingjie, School of Education, Beijing Normal University, China.

Juana M. Sancho Gil, University of Barcelona, Spain.

Manuela du Bois-Reymond, Universiteit Leiden, Netherlands.

Mario Bello, University of Science, Technology and Environment, Cuba.

Miguel A. Pereyra, University of Granada, Spain.

José-Luis Ortega, University of Granada, Spain.

Daniel Madrid Fernandez, University of Granada, Spain.

Francisco Fernandez Palomares, University of Granada, Spain.

ASSOCIATE EDITORS, 2005

Visit: http://www.Learning-Journal.com

SCOPE AND CONCERNS

Visit: http://www.Learning-Journal.com

SUBMISSION GUIDELINES

Visit: http://www.Learning-Journal.com

INQUIRIES

Email: cg-support@commongroundpublishing.com 